\title{
Mapping Intrinsic Vulnerability to Pollution Using the DRASTIC Method in the Temara Groundwater (Northwestern Morocco)
}

\author{
Mariam Taazzouzte, Ben'Msik Faculty of Sciences, Hassan II University, Morocco* \\ Abdessamad Ghafiri, Ben'Msik Faculty of Sciences, Hassan II University, Morocco \\ Hassan Lemacha, Ben'Msik Faculty of Sciences, Hassan II University, Morocco \\ Saida El Moutaki, Ben'Msik Faculty of Sciences, Hassan II University, Morocco \\ Imane Haidara, Ben'Msik Faculty of Sciences, Hassan II University, Morocco
}

\begin{abstract}
The DRASTIC method was chosen because it can be adapted to different environments and because it combines the seven criteria that directly influence groundwater: depth, recharge, geology, soil, slope, unsaturated zone, and conductivity. Located in the North West of Morocco, the Temara aquifer is a very important water resource, but it is overexploited and deteriorated. This issue is of concern to decision-makers in the field of water management. The objective of this work is to create a map of vulnerability to pollution by the Bay of Geographic Information Systems (GIS) and the DRASTIC model. Thus, the highest vulnerabilities are located around the drinking water treatment plant of Ain Atiq, at the mouth of the Bouregreg River, and scattered in places throughout the study area. The results of the physico-chemical analysis showed compatibility with the results of the DRASTIC model.
\end{abstract}

\section{KEYWORDS}

Analysis, DRASTIC, Mapping, Physico-Chemical, Sig, Temara Groundwater, Vulnerability

\section{INTRODUCTION}

Groundwater is a precious natural resource, it has become increasingly rare all over the world. This scarcity stems from, on one hand, the overexploitation in domestic, industrial and agricultural fields. On the other hand; from unprecedented population and urban growth. Compared to surface water, groundwater is less exposed to the risks of pollution because it exists in depth (Li and al., 2018; Wang and al., 2019; Arya and al., 2020). However, groundwater remains susceptible to intrinsic pollution due to agricultural and anthropogenic activities (Voudouris and al., 2010; Aravinthasamy and al., $2019 \mathrm{~b}$ and Tomer and al., 2019).

The heavy impact of this problem on groundwater quality has become a major concern for all countries of the world. Therefore, this has triggered governments to develop water management programs through academic studies on groundwater vulnerability to pollution.

In 1968, Margat introduced the concept of groundwater vulnerability. The latter contradicts with the basic role of natural barriers in protecting groundwater from contamination (Margat, 1968). In other words, it is the tendency and probability of contaminants in reaching the aquifer after being 
introduced to the soil surface (Ball and al., 2004, Mahmudul and al., 2019). In fact, several research studies have applied various models which utilize Geographic Information Systems (GIS) as an indispensable tool. These models are based on the layering process of the various factors involved in groundwater's vulnerability to pollution, for instance DRASTIC (Aller and al., 1987; Bera and al., 2021; Agossou and Yang, 2021 ; Voutchkova and al., 2021), GOD (Foster, 1987 ; Boulabeiz and al., 2019; Taazzouzte and al., 2020), AVI (Van Stempvoort and al., 1993), EPIK (Doerfliger and Zwahlen, 1997; Nekkoub and al., 2020), SINTACS (Civita, 1994 ; Noori and al., 2019), PCA technique (Rahmani and al., 2019), FIS (Pathak and Bhandary., 2020) Fuzzy Clustering (Javadi and al., 2020). It is worth noting but the selection of the method depends on the purpose of the study and the availability of the data.

Indeed, the DRASTIC method that has been applied in this work is the most used standard model all over the world. It is based on the principle of standardization and the weighing of seven hydrogeological parameters which depends on the importance of each one and its relation to the vulnerability of groundwater. Indeed, there are multiple recent works on the DRASTIC method. To name a few, in India, there is a study on "The In-Depth Evaluation of the DRASTIC Index for the Study of Groundwater Vulnerability to Pollution in the Semi-Arid Vattamalaikarai River" (Arya and al., 2020). Within the same country, there is an academic research on "The Spatial Assessment of Groundwater Vulnerability by The DRASTIC Model In The Uppar Odai Subwatershed, Na Ndiyar, Cauvery Basin, Tamil Nadu, India" (Bhuvaneswaran and Ganesh, 2019). In Egypt, researchers have conducted a case study named "The Assessment of Groundwater Quality in The El Fayoum Depression by The DRASTIC Model" (Gad and El-Hattab, 2019). In Iran, another example targets "A Comparison Study of DRASTIC Methods with Various Objective Methods for Groundwater Vulnerability Assessment from the Sari-Behshahr Plain to northern Iran (Khosravi and al., 2018). In Ethiopia, researchers analyzed the vulnerability of groundwater in the Tana sub-basin using the DRASTIC method (Abiy and al., 2016). In Portugal, there is a study aiming at assessing the vulnerability of groundwater to pollution using the DRASTIC method (Duarte and al.,2014). Finally, in Morocco, researchers carried out a comparative approach of three popular intrinsic vulnerability methods in the area of Beni Amir (Morocco) (Knouz and al., 2018). It is worth noting, the fact that all the aforementioned studies have shown that the DRASTIC method is the adequate model to evaluate the vulnerability of groundwater. Therefore, the purpose of this paper is to produce an intrinsic pollution vulnerability map using the DRASTIC method. This map will represent a technical and scientific support for decision makers. Moreover, it will allow them to install specific groundwater management and development programs to the area in question.

The Témara aquifer is our study area. It is the only groundwater source that supplies the city of Rabat, the political capital of Morocco, and the city of Témara. These two metropolises are witnessing an important socio-economic development. These changes affect the quality of groundwater used in agricultural and domestic activities. Therefore, this may put the health of the whole population at a risk.

\section{Main Focus of the Article}

The main objective of this study is to find practical solutions to facilitate the control of groundwater quality, at the level of the most vulnerable points to pollution. This can be achieved by applying the DRASTIC method which aims at producing a map that delineates, gradually the zones which are vulnerable to intrinsic pollution. Therefore, this map will represent a technical and scientific support for decision makers. Moreover, it will allow them to install specific groundwater management and development programs to the area in question. 


\section{Study Area}

\section{Geographical Framework}

The Temara groundwater belongs to the coastal strip of northern Morocco, and it is part of the Bouregreg watershed (Figure 1). It is characterized by a semi-arid climate with an average annual temperature ranging from $17 \mathrm{pC}$ to $18 \mathrm{pC}$, an evaporation ranging from 1500 to $1600 \mathrm{~mm}$ per year, also an irregular and low precipitation at the national level (ABHBC, 2019). The water coming from this aquifer is used to supply drinking water to the towns of Temara and Ain ATIQ to irrigate many plots used for the development of market gardening.

Figure 1. Geographical Location Map of Skhirat-Temara groundwater

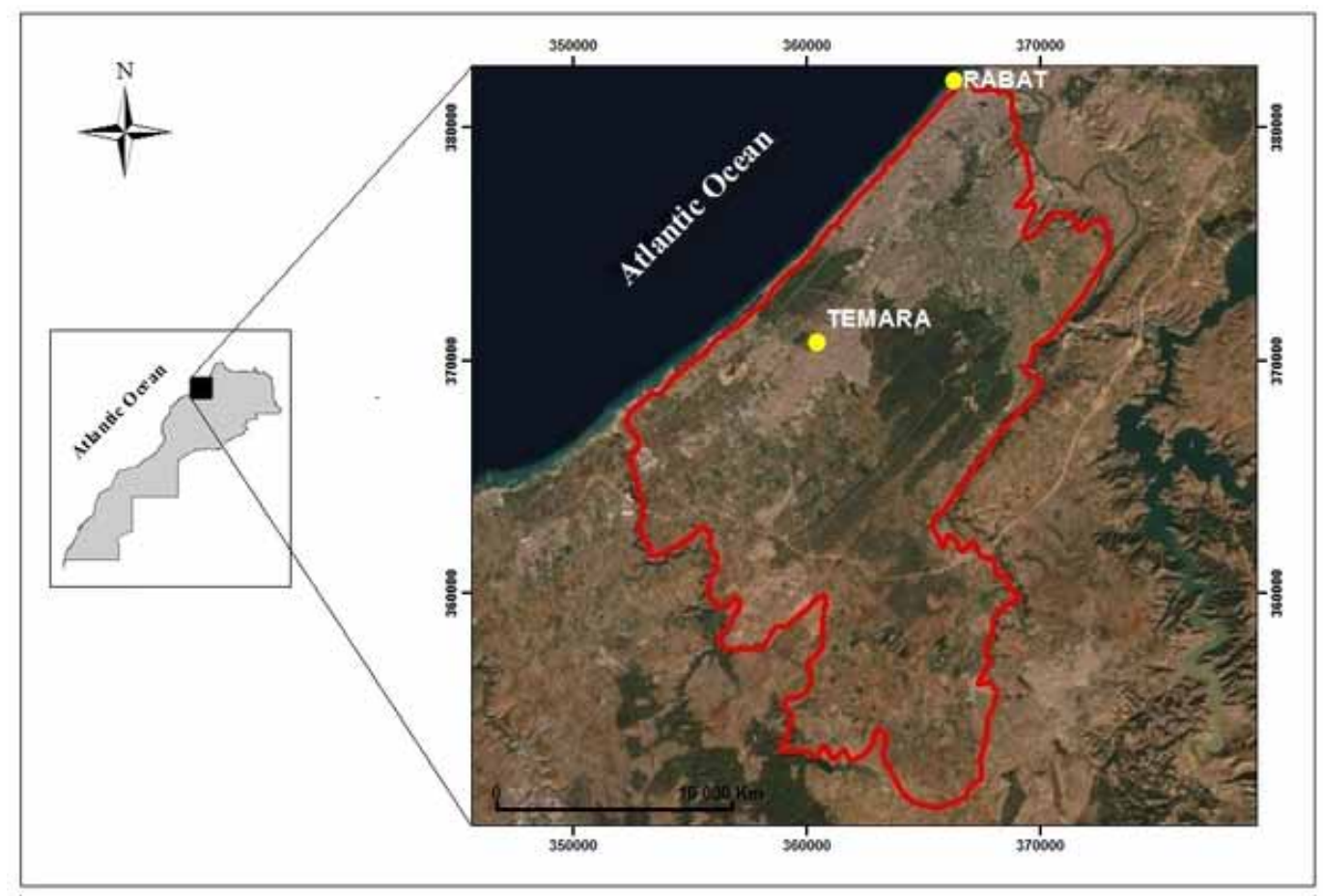

\section{Geological and Hydrogeological Framework}

The groundwater of Témara belongs to the Moroccan coastal Meseta made up of plains and plateaus. The coastal Meseta has a morphology which is slightly inclined towards the Atlantic, and it extends from Safi to the vicinity of Rabat. The bleachers are covered by a system of shoreline cords built up of plio-quaternary calcarenites of marine and wind origin (Beaudet and al., 1967; Beaudet, 1969; Stearns, 1978; Akil, 1980; Lefèvre and Raynal, 2002). Primary lands are heavily folded, tectonized and leveled off (Combe, 1963). Between the first cordon and a line of dead cliffs, there is a gutter or furrow, a depression more or less parallel to the rib line, commonly called « Oulja » (Figure 2) (Guilcher and Joly, 1954; Weisrock, 1980; Weisrock and Fontugne, 1991).

The aquifer of Temara contains a groundwater developed in the formations of the tertiary cover. The latter consists of permeable Plio-quaternary sizzling limestones. The water proof substrate of the study area is made up of Miocene marls to the northeast, and Paleozoic shale to the southwest. 
Figure 2. Geological map of coastal Meseta

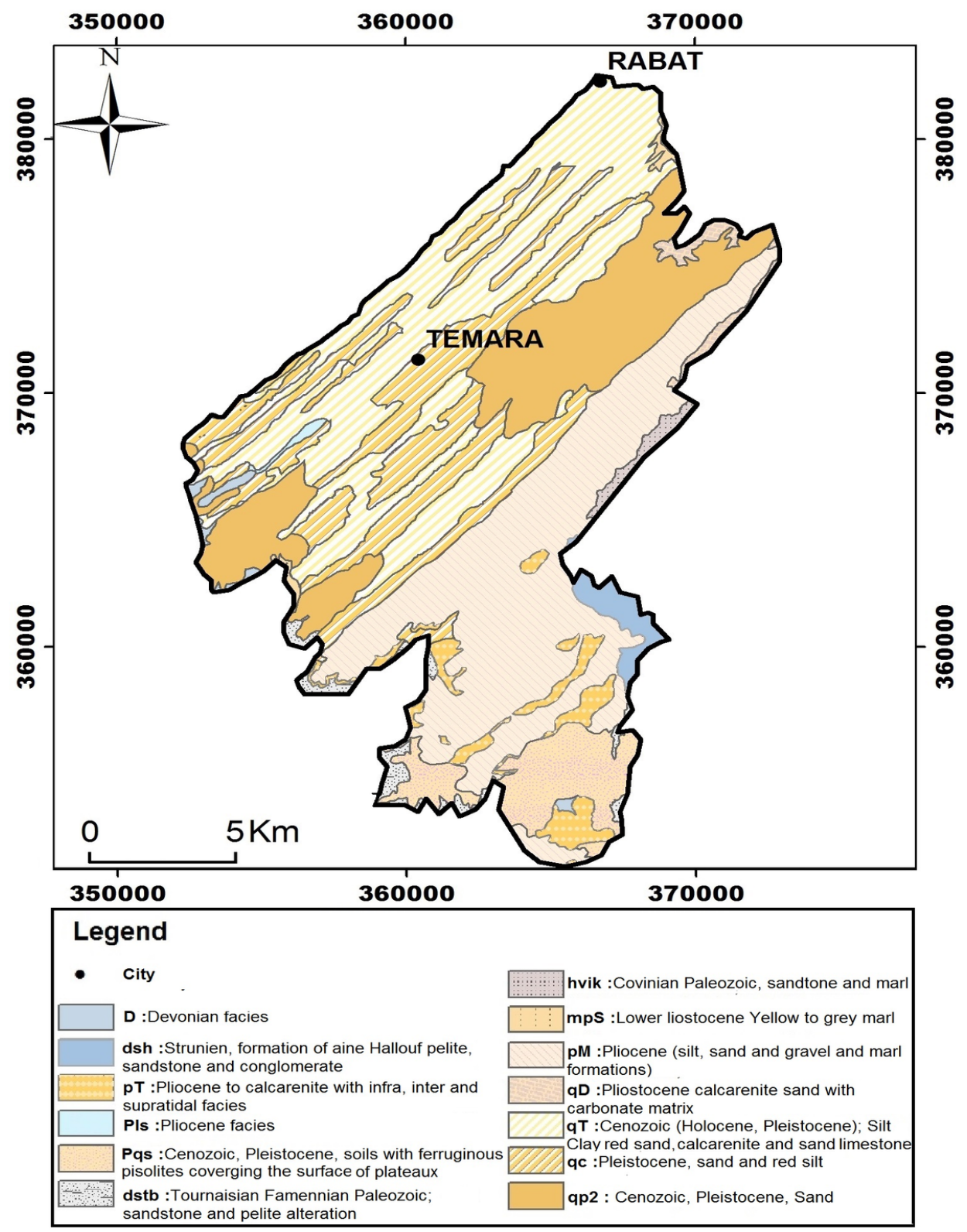

Regarding the hydrogeological level, the aquifer of Temara is a well individualized water table. It extends over nearly $350 \mathrm{~km}^{2}$, it exists between the deep valleys of Oued Bouregreg and its tributaries of Oueds Akrach, Ikem and the Atlantic Ocean (Amraoui, 2000).

It is supplied by precipitation. The piezometric level of the zone (Figure 3) reaches a maximum of $250 \mathrm{~m}$, and it decreases following the direction of the flow, from the Southeast to the Atlantic Ocean to the northwest. Based on the analysis of geological documents and reconnaissance drilling data (48 wells) retrieved from the agency of hydraulic basins Bouregreg-Chaouia (ABHC) and the results of field trips, we have observed the presence of sedimentary gaps with lateral variaton in places. 
Figure 3. Lithological cuts in the study area (Amraoui, 2000)

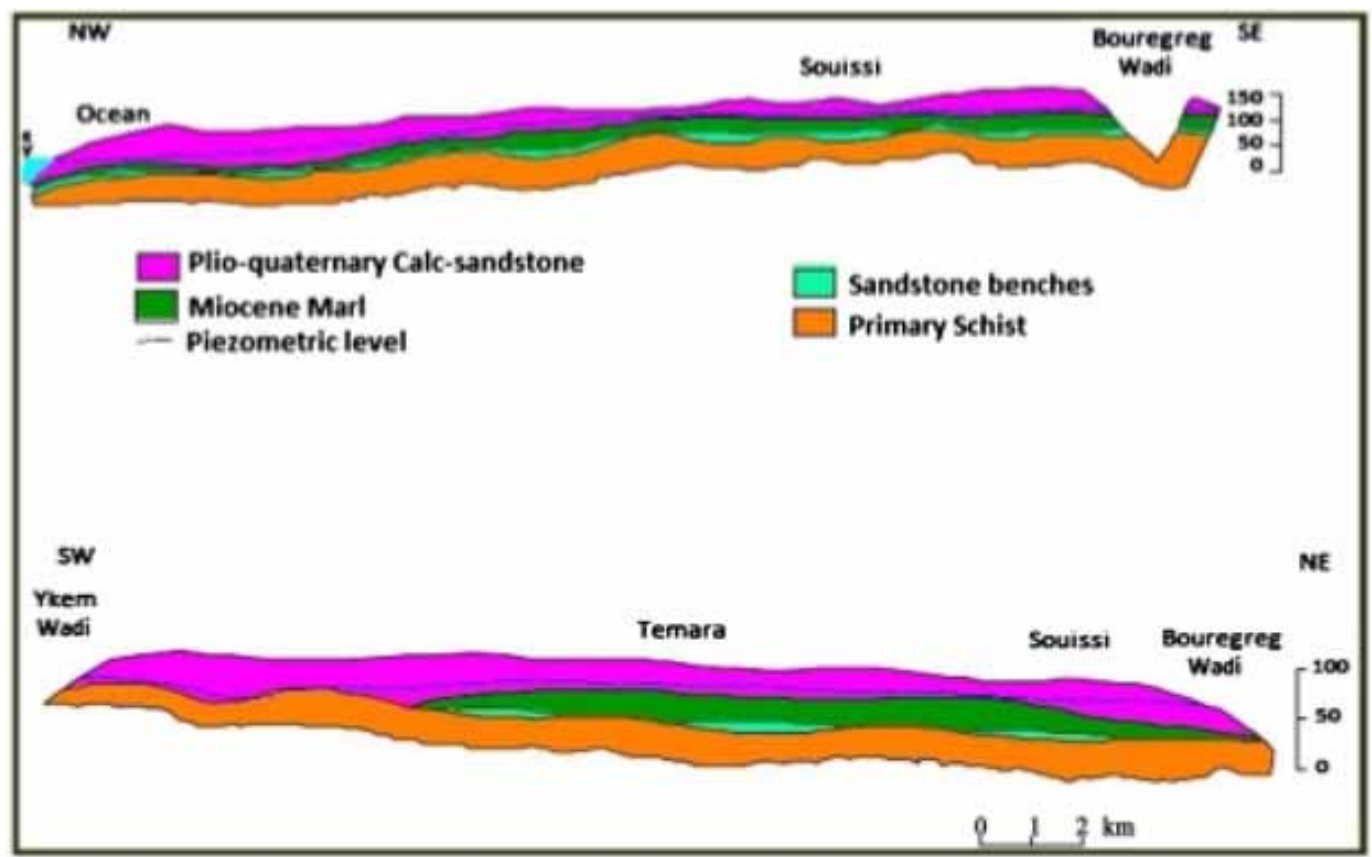

\section{METHODOLOGY}

The DRASTIC Method is used to assess groundwater vulnerability to pollution. It was developed in the 1980 by the American Environmental Protection Agency services (USEPA - ALLER and al., 1987). It is based on the calculation of a numerical index obtained by multiplying the coast of each parameter by its relative weight (Table 1) and by making the sum of these products according to the following formula:

$D R A S T I C$ Indice $=D c \cdot D p+R c \cdot R p+A c \cdot A p+S c \cdot S p+T c \cdot T p+I c \cdot I p+C c \cdot C p$

where:

- 'c': Ranting allocated to each parameter.

- 'p': Weight allocated to each parameter.

Table 1 presents the DRASTIC method with its seven parameters. Each parameter is defined by its range, raring, and weight. 
Table 1. Ranting and weight of the seven parameters DRASTIC (Aller and al., 1987)

\begin{tabular}{|c|c|c|c|}
\hline Parameter & Range & Ranting & Weight \\
\hline Depth to water table (m) & $\begin{array}{l}0-1,5 \\
1,5-4,6 \\
4,6-9,1 \\
9,1-15,2 \\
15,2-22,9 \\
22,9-30,5 \\
>30,5\end{array}$ & $\begin{array}{l}10 \\
9 \\
7 \\
5 \\
3 \\
2 \\
1\end{array}$ & 5 \\
\hline Net Recharge (mm) & $\begin{array}{l}11,0-13,0 \\
9,0-11,0 \\
7,0-9,0 \\
5,0-7,0 \\
3,0-5,0\end{array}$ & $\begin{array}{l}10 \\
8 \\
5 \\
3 \\
1\end{array}$ & 4 \\
\hline Aquifer media & $\begin{array}{l}\text { Massive schist, sandstone and limestone beds } \\
\text { Solid sandstone, limestone, sand and gravel } \\
\text { Beds of sandstone, limestone and shale } \\
\text { Limestone, sand and gravel } \\
\text { Limestone Schist and Basalt } \\
\text { Limestone and Basalt }\end{array}$ & $\begin{array}{l}3 \\
4 \\
5 \\
6 \\
8 \\
9\end{array}$ & 3 \\
\hline Soil media & $\begin{array}{l}\text { Rubble, Sand, Clay and Silt } \\
\text { Gravel and Sand } \\
\text { Gravel, Sand, Clay and Silt } \\
\text { Sand } \\
\text { Sand, Clay, Silt } \\
\text { Clay and Silt }\end{array}$ & $\begin{array}{l}9 \\
7 \\
6 \\
5 \\
3 \\
2\end{array}$ & 5 \\
\hline $\begin{array}{l}\text { Topography } \\
\text { (m) }\end{array}$ & $\begin{array}{l}0-2 \\
2,0-6,0 \\
6,0-12,0 \\
12,0-18,0 \\
>18\end{array}$ & $\begin{array}{l}10 \\
9 \\
5 \\
3 \\
1\end{array}$ & 1 \\
\hline Impact of vadose zone & $\begin{array}{l}\text { Silt or Clay } \\
\text { Sandstone, Limestone and Schist } \\
\text { Sand and Gravel } \\
\text { Limestone, sandstone } \\
\text { Sand and Gravel with Silt and Clay } \\
\text { Karstic limestone and Basal }\end{array}$ & $\begin{array}{l}3 \\
4 \\
5 \\
6 \\
8 \\
9\end{array}$ & 5 \\
\hline $\begin{array}{l}\text { Hydraulic Conductivity } \\
(\mu \mathrm{S})\end{array}$ & $\begin{array}{l}0-4,1 \\
4,1-12,2 \\
12,2-28,5 \\
28,5-40,7 \\
40,7-81,5\end{array}$ & $\begin{array}{l}1 \\
2 \\
4 \\
6 \\
8\end{array}$ & 3 \\
\hline
\end{tabular}

1. Depth of water table D: This parameter represents the vertical distance between the ground surface and the water table. The shorter the distance from the soil surface and the water table, the greater the vulnerability of groundwater. The depth map was made from the interpolation of the piezometric levels of 48 wells by the krigeage method.

2. Net recharge R: This parameter is very important because it directly influences the vulnerability of the water table to pollution, especially for open water that is supplied by rainwater. This recharge can affect the vertical transport of contaminants to the water table and can spread horizontally into the aquifer (Aller and al., 1987a). The recharging map is made by combining three factors: slope, efficient precipitation and permeability. 
3. Aquifer media A: This parameter takes the size and nature of the particles forming the geological layers that make up the aquifer into account. The lithological map was made from the digitalization of the geological map.

4. Soil media S: Soil texture affects the amount of infiltration. The soil map was made from the digitalization of the soil map.

5. Topography T: Water infiltration is more important when land is characterized by low slopes, which promotes runoff and therefore increases the risk of contamination. The slope map was based on the digital terrain model (MNT).

6. Impact of vadose zone I: This parameter characterizes areas where pores are partially filled with water, so the porosity and the permeability of rocks impact groundwater contamination. There is generally a variation in the thickness as we move in depth. The map of the unsaturated area was made from the geological map.

7. Hydraulic Conductivity C: Hydraulic conductivity is the force that allows water to be transmitted into the pores of the soil. High conductivity promotes groundwater contamination. This parameter was obtained from the interpolation of hydraulic conductivity measurement results at the level of 48 wells covering the study area.

\section{RESULTS AND INTERPRETATION}

\section{Depth to Water Table D}

The depth of the groundwater does not usually exceed 20 metres at the western part of the study area. For the rest of the aquifer, it exceeds 20 meters, especially in the central and southern area (Figure 4).

\section{Net Recharge $\mathbf{R}$}

The recharge at the table is remarkably different, with values exceeding $11 \mathrm{~mm}^{3} /$ year located south of the city of Rabat, along the left bank of the Oued Bouregreg, south-west of the town of Ain Atiq, Mers Elkhir and in the Forest of Menzeh. For the rest of the area, the recharge values do not exceed $5 \mathrm{~mm}^{3} /$ year (Figure 5).

\section{Aquifer Media A}

The water table of Temara is part of the coastal strip of the coastal Meseta developed in the Tertiary cover (Figure 6). It is a well-individualized aquifer on a hydrogeological level and it is formed by:

- Thin sandstone benches topped with Plio-quaternary calcarenistic levels.

- Detritus yellow sands topped by grey marls of the Prepliocene Self.

- Carboniferous limestone sandstone formations.

- Devonian reef or pre-reef limestone.

\section{Soil Media S}

The groundwater of Temara is characterized by the dominance of two soil types (Figure 7). First, iron-coated soils cover the majority of the study area from the centre to the southwest. Second, in the north and south-east, it is the low-developed erosion soils with the inclusion of raw minerals that dominate in the region.

\section{Topography T}

The slopes of the study area are low (Figure 8 ). They do not exceed the value of 5\%, which characterizes the Mesetien domain generally known as tabular structures. 
International Journal of Agricultural and Environmental Information Systems

Volume 12 Issue 4

Figure 4. Depth of water table of the study area

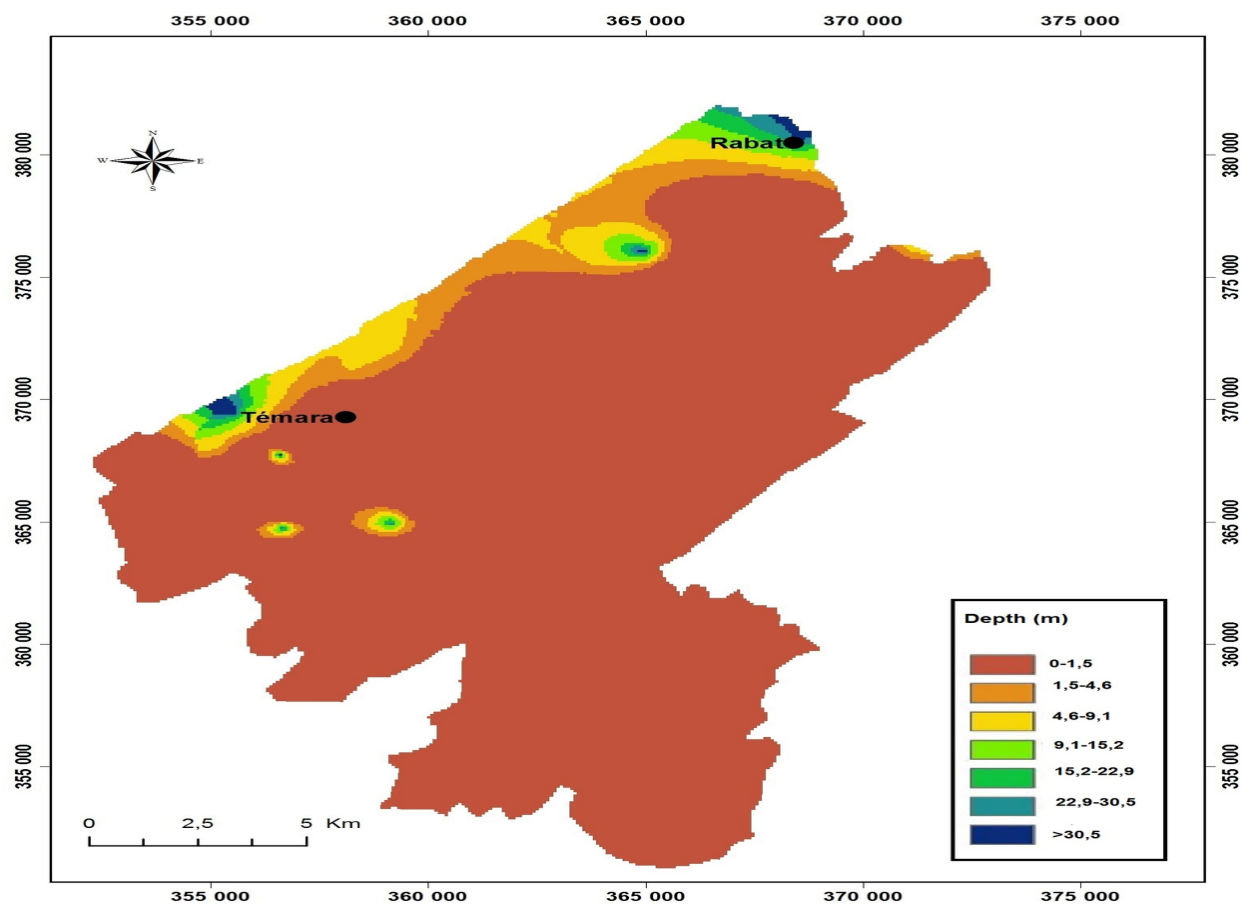

Figure 5. Net Recharge Map of the study area

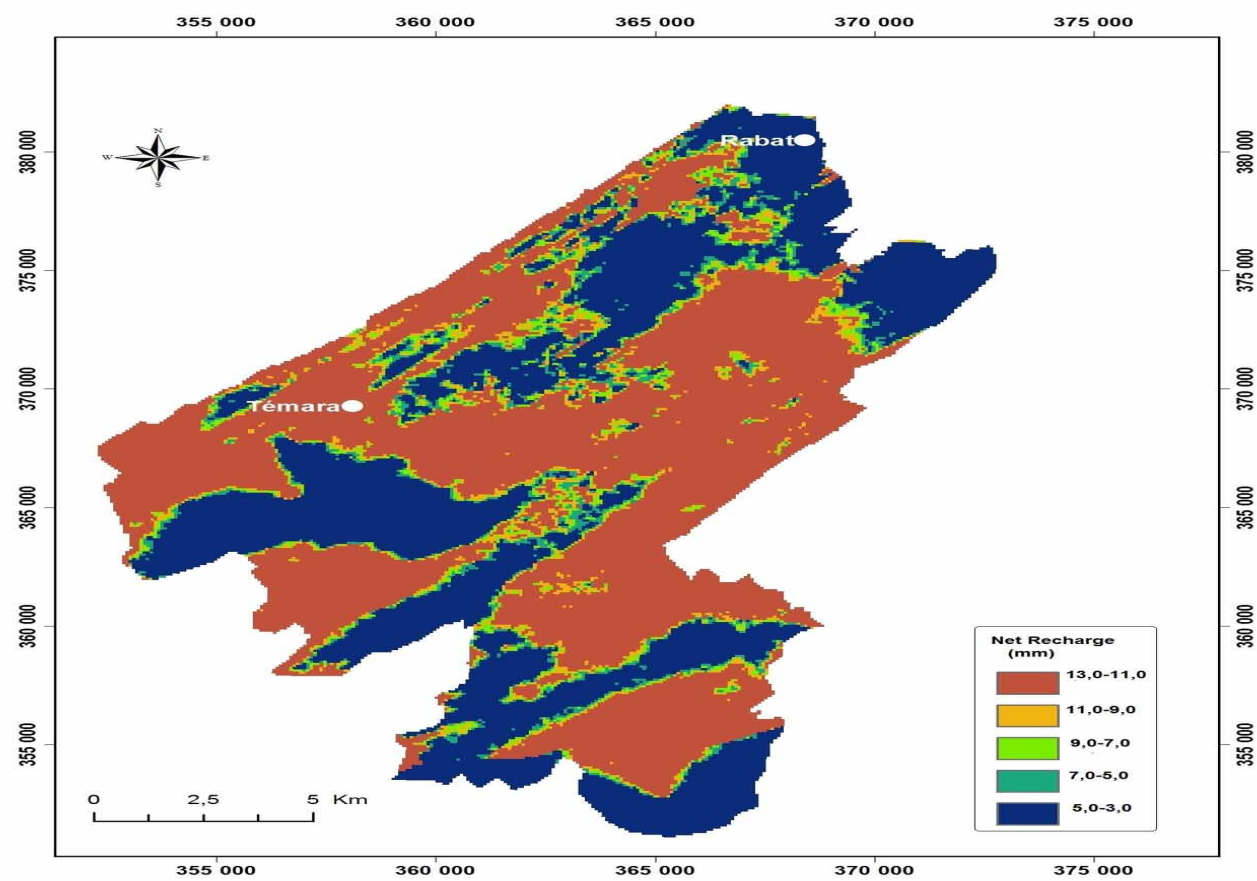


Figure 6. Aquifer media Map of the study area

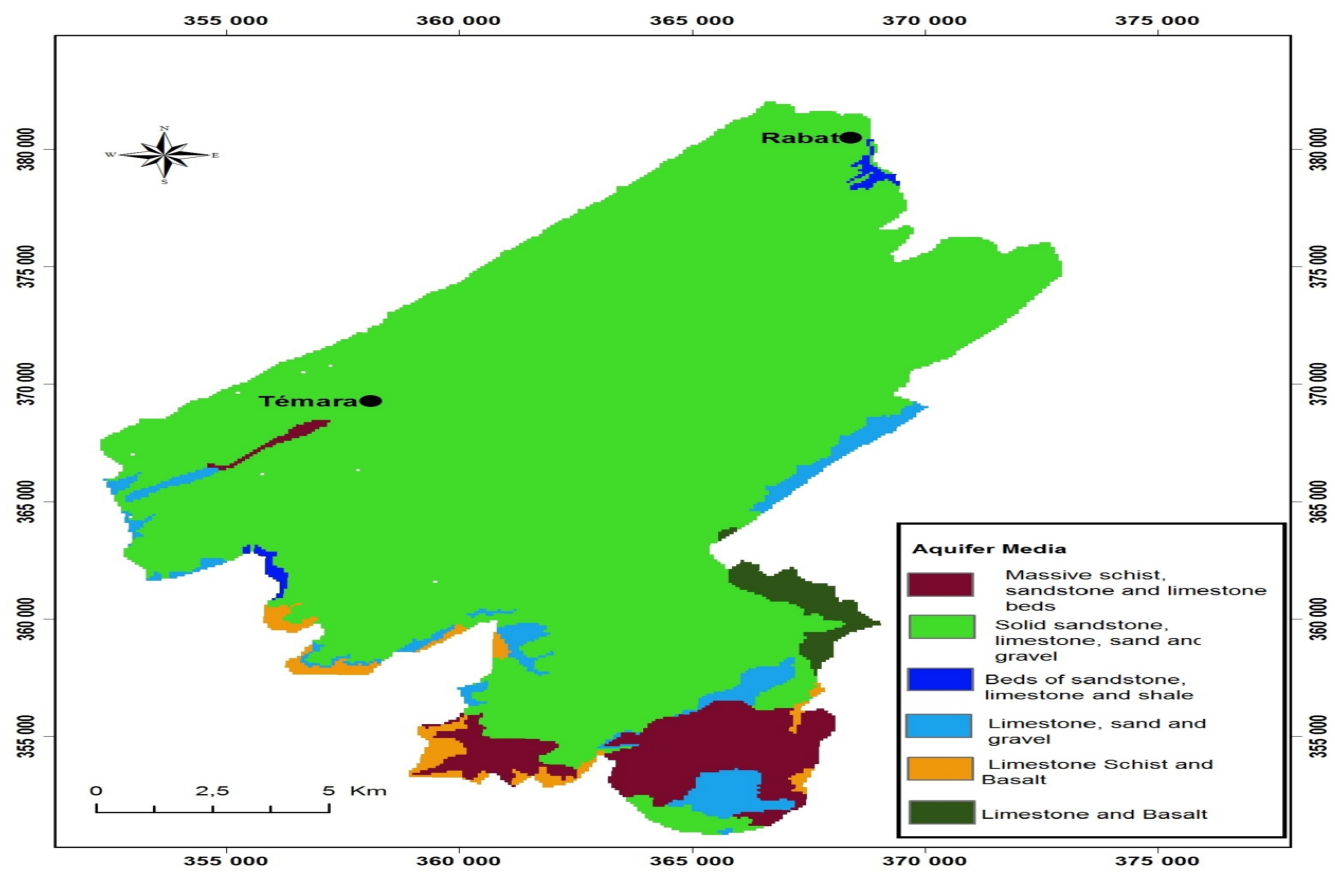

Figure 7. Soil media Map of the study area

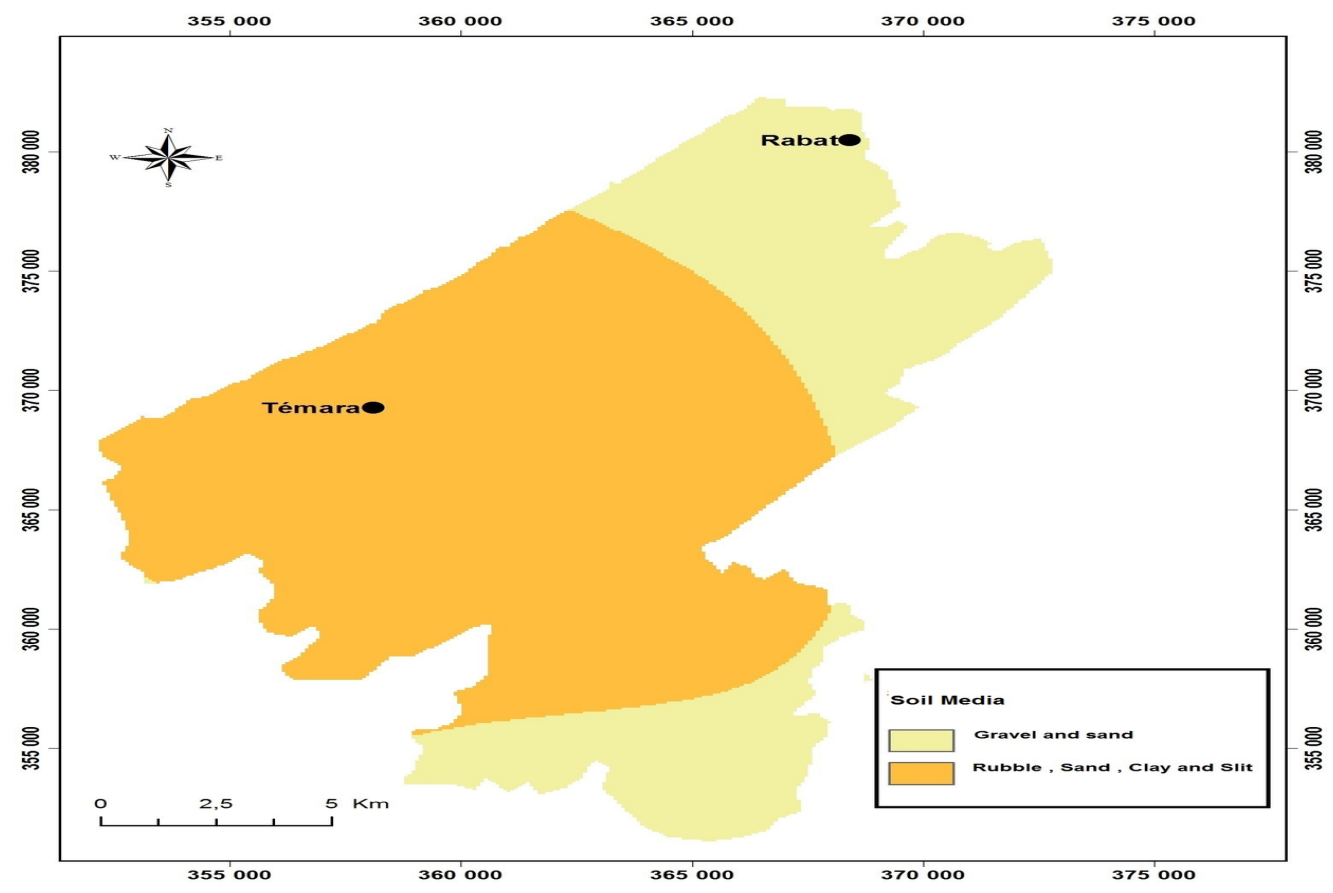


Figure 8. Topography Map of the study area

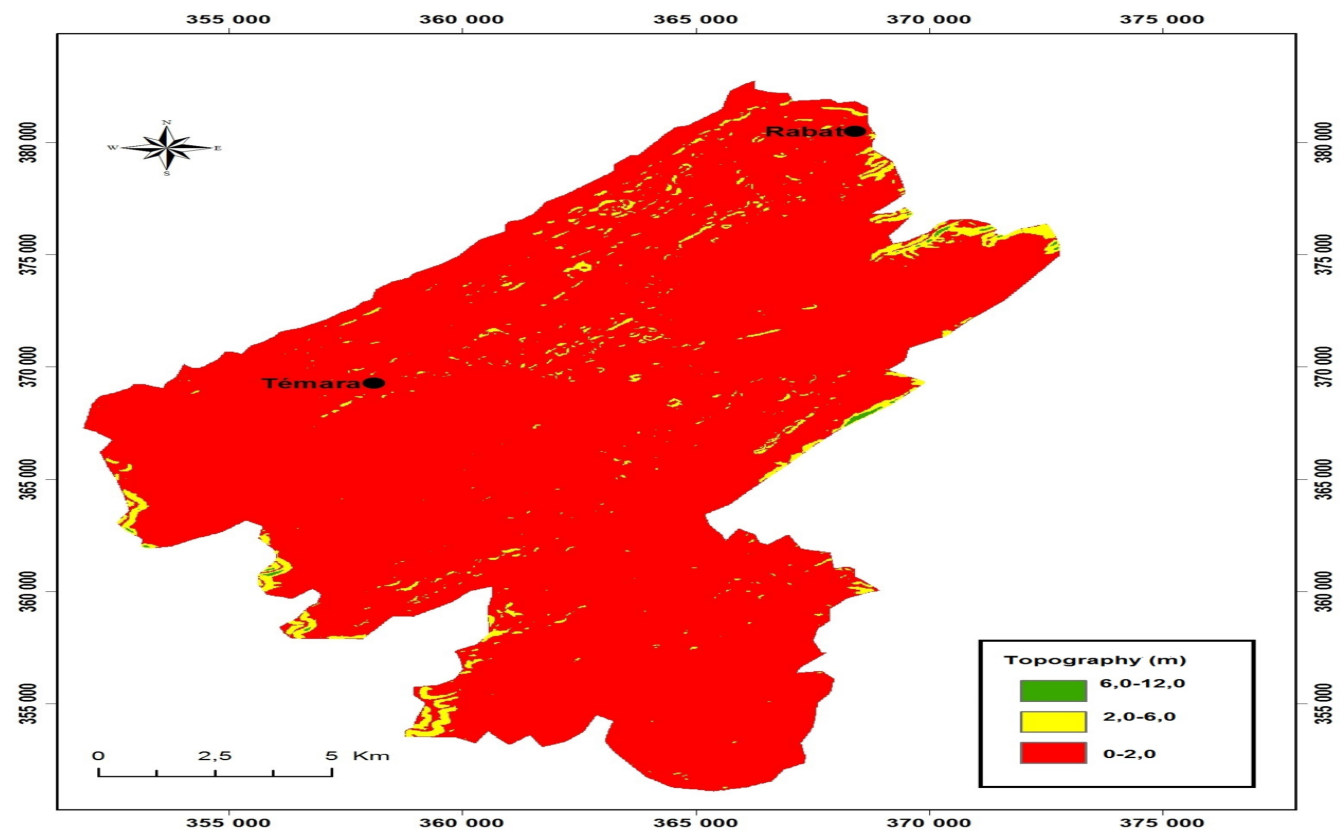

Figure 9. Impact of zone vadose Map of the study area

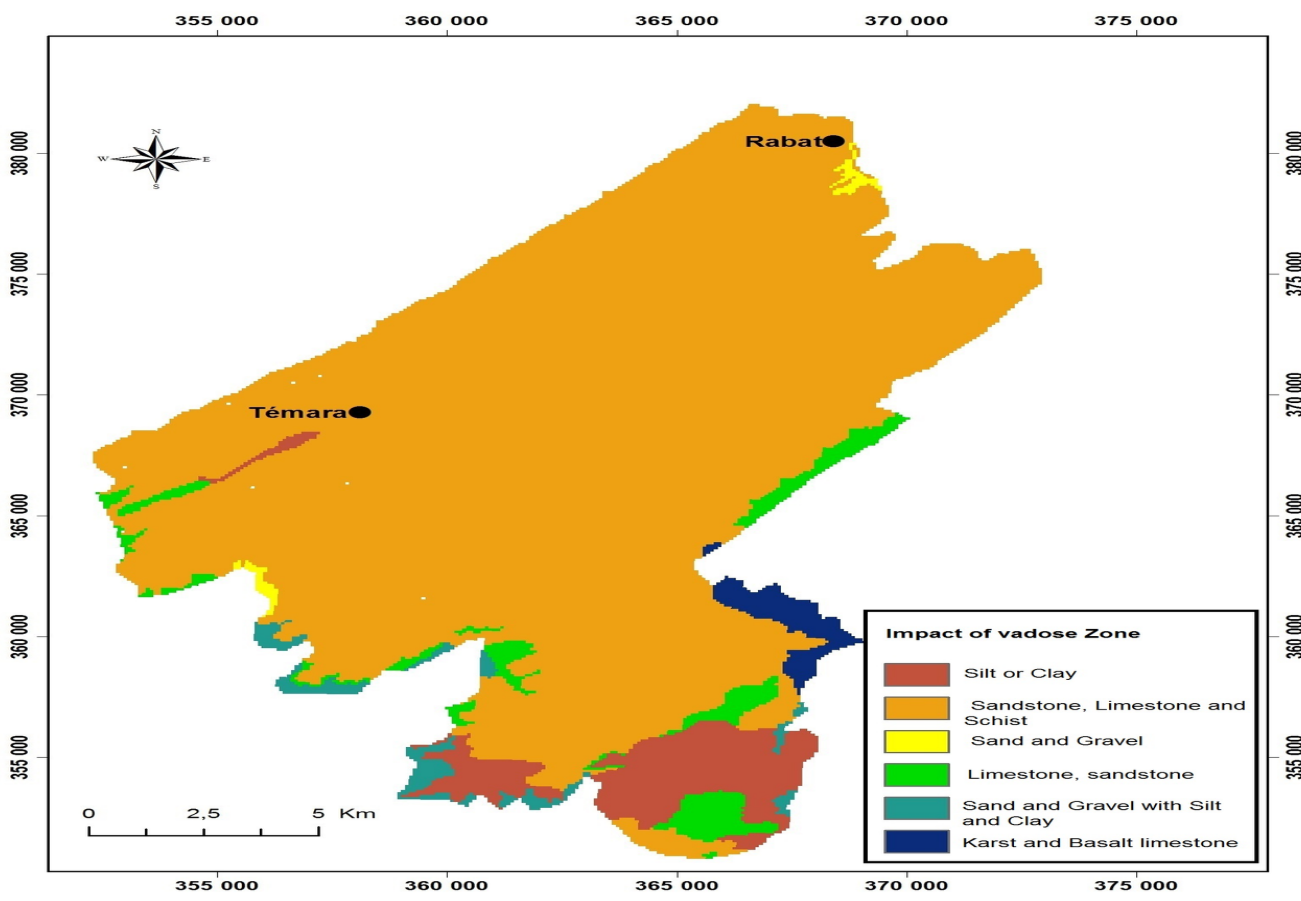




\section{Impact of Vadose Zone I}

The vadose zone is defined as the area above the water table that is unsaturated or saturated intermittently (Aller and al., 1987). It is characterized by good permeability, thus facilitating the infiltration of polluting water that will percrate to the aquifer layer (Figure 9).

\section{Hydraulic Conductivity C}

Hydraulic conductivity represents the ability of aquifer materials to transmit water to control the rate at which groundwater will flow under a specified hydraulic gradient. With the increase in hydraulic conductivity, the speed of groundwater and the rate at which pollutants are transported also increases, resulting in an increase in the vulnerability of aquifers (Shweta Kumari, 2016). The distribution of electrical conductivity values varies between 4.1 and $12.2 \mathrm{mS}$ in the majority of the study area while values vary between 28.5 and $40.7 \mathrm{mS}$ covering the southern part (Figure 10).

Figure 10. Hydraulic conductivity Map of the study area

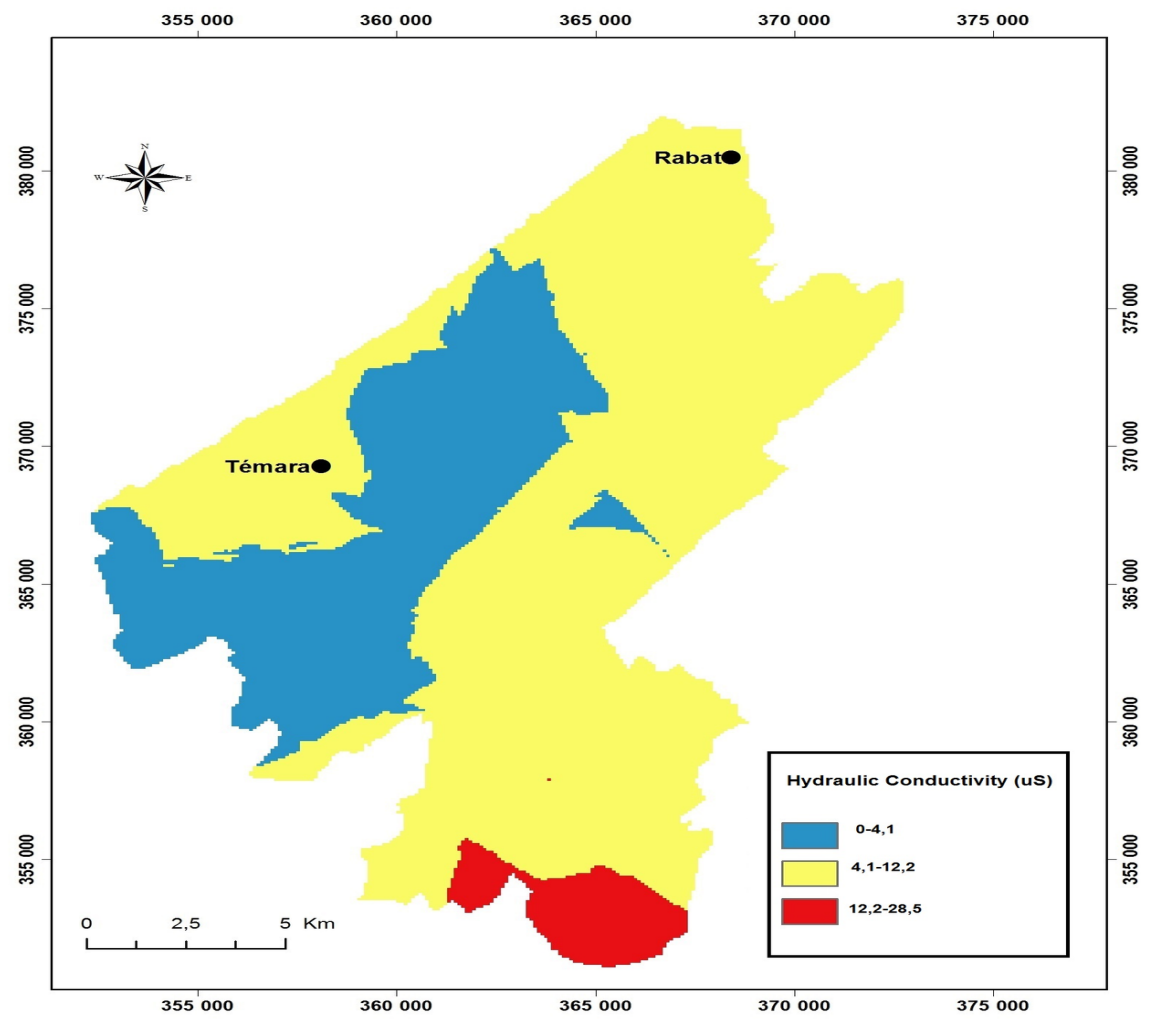

\section{The Vulnerability Index}

The groundwater pollution vulnerability index is calculated from the sum of parameters that are already standardized and weighted basing on their importance, according to the formula:

Indice DRASTIC $=D .5+R .4+A .3+S .2+T .1+I .5+C .3$ 
The result of the DRASTIC index is classified into 5 classes: very low, low, medium, strong and very strong vulnerability. Thus, the vulnerability map obtained (Figure 11) shows the distribution of the areas most vulnerable to pollution around the city of Rabat, near the mouth of Bouregreg river and the Drinking Water Treatment Plant of Ain Atiq (STEP). On the other hand, the zones representing a medium vulnerability cover the extremities of the aquifer where urbanization is dominant and consequently the rate of domestic wastewater discharges becomes more and more important, these discharges infiltrates directly into the aquifer and influence its vulnerability. Areas where the vulnerability of the groundwater tends from low to very low are located in the center of the study area which knows a very important vegetation represented by the forests of El Menzeh and Mers Elkhir municipalities, and the green spaces in the western part.

Figure 11. The pollution vulnerability Map of Temara groundwater

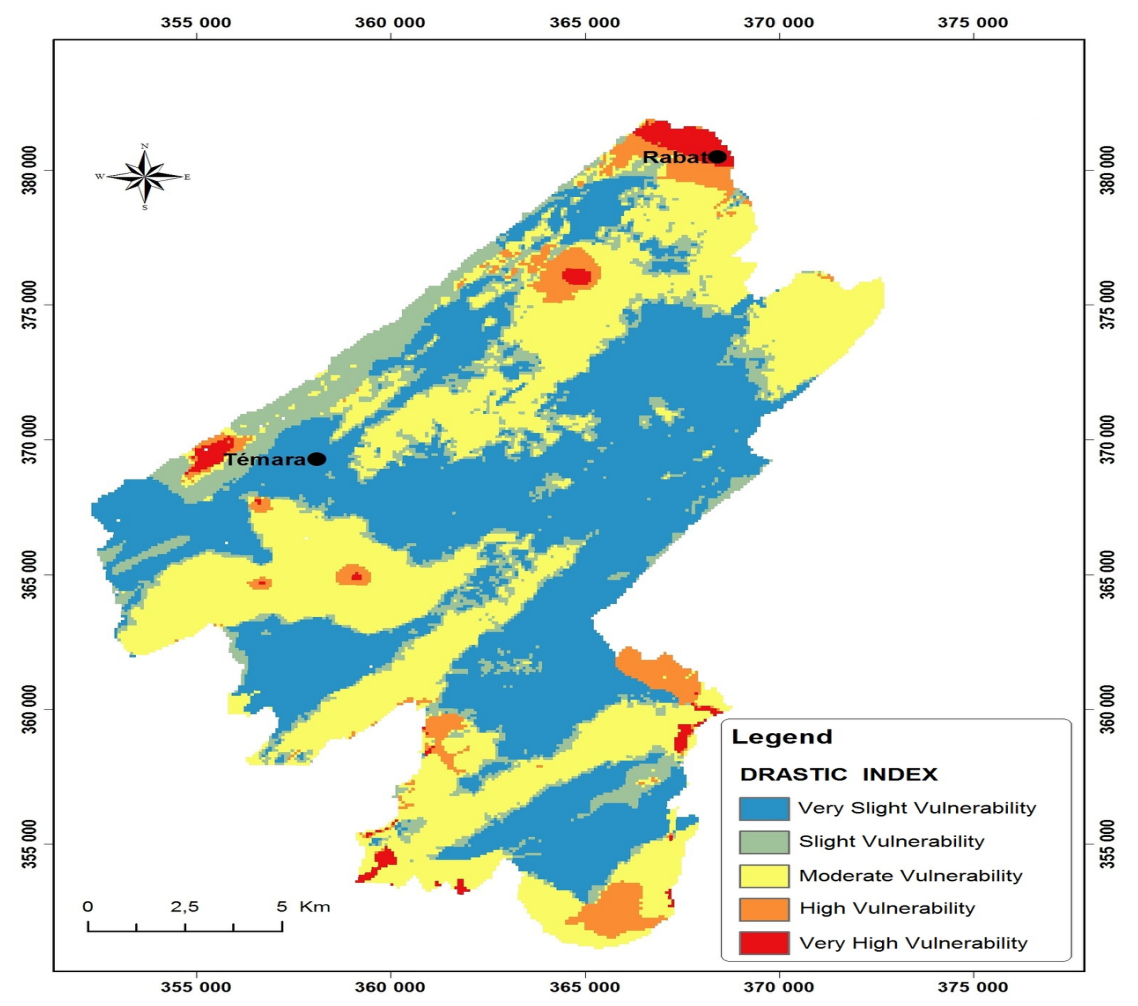

To validate the results obtained in the pollution vulnerability Map through the application of the DRASTIC method, physico-chemical analyses of groundwater were carried out on samples taken from 48 wells covering the entire study area during the low water period.

The parameters studied are: Temperature, $\mathrm{Ph}$, Conductivity, Nitrates and Chlorides which are the main indicators of groundwater pollution.

The temperature of the well water is relative to the season and also to the time the sample is taken. It is still standard that the temperature of the entire area does not exceed 25 degrees Celsius. The results obtained for other parameters are shown in table 2. 
Table 2. Results of physico-chemical analysis against the DRASTIC index

\begin{tabular}{|c|c|c|c|c|c|}
\hline & \multicolumn{4}{|c|}{ Physico-chemical } \\
\hline & & PH & $\begin{array}{c}\text { Electrical } \\
\text { Conductivity }(\mu \mathrm{S})\end{array}$ & Nitrates (mg/l) & $\begin{array}{c}\text { Chlorides } \\
\text { (mg/l) }\end{array}$ \\
\hline \multirow[t]{5}{*}{$\begin{array}{l}\text { Vulnerability } \\
\text { degree } \\
\text { parameter }\end{array}$} & $\begin{array}{l}\text { Very High } \\
\text { Vulnerability } \\
\text { (Red) }\end{array}$ & 7,31 & 3490 & 257,87 & 125 \\
\hline & $\begin{array}{l}\text { High } \\
\text { Vulnerability } \\
\text { (Orange) }\end{array}$ & 7,31 & 2330 & 227,03 & 110 \\
\hline & $\begin{array}{l}\text { Moderate } \\
\text { Vulnerability } \\
\text { (Yellow) }\end{array}$ & 7,4 & 1982,33 & 159,5 & 105,1 \\
\hline & $\begin{array}{l}\text { Slight } \\
\text { Vulnerability } \\
\text { (Green) }\end{array}$ & 7,32 & 1870,6 & 98,37 & 90,82 \\
\hline & $\begin{array}{l}\text { Very Slight } \\
\text { Vulnerability } \\
\text { (Blue) }\end{array}$ & 7 & 847 & 70,5 & 29,82 \\
\hline
\end{tabular}

- PH water (pH): provides information on the acidity and alkalinity of the waters and it conditions the solubility of metals in the waters. At the level of the study area, the values of this parameter range from 7 to 7.4. It is a slightly alkaline $\mathrm{Ph}$ that does not represent a large variation for the majority of the water of the slick. This alkalinity is the result of the abundance of limestone formations in the Temara aquifer.

- Electrical Conductivity (CE): It gives an idea of the degree of mineralization of the waters. The value of this setting ranges from $847 \mathrm{~S}$ to $3490 \mathrm{~S}$. It allows these waters to be classified according to Moroccan groundwater quality standards varying from good to very bad (SEEE, 2007). The important values appear to be the result of leaching of the reservoir rock in which the waters were staying.

- Nitrate (NO3-): The high nitrate content is an indicator of groundwater pollution. In the study area, average nitrate concentrations range from $70.5 \mathrm{mg} / \mathrm{l}$ to $257.87 \mathrm{mg} / \mathrm{l}$. Therefore, the underground waters of this region are classified according to Moroccan standards varying from bad to very bad (SEEE, 2007). This degradation appears to be mainly due to agricultural activity using nitrogen fertilization and wastewater.

- Chlorides (Cl-): These anions are indicators of pollution that exist in all waters at variable concentrations. They may have a natural origin, leaching of salt layers rich in sodium salts or infiltration of marine waters into the water table or human activity. The concentration of this element throughout the study area does not exceed $200 \mathrm{mg} / 1$. This places them in the excellent category according to the Moroccan standards for the quality of groundwater (SEEE, 2007).

The variation in the results of the physico-chemical analysis of the above-mentioned elements, according to those of the DRASTIC index, is represented in Figure 12.

In the areas of very high vulnerability (red), the average level of electrical conductivity is in the order of $3490 \mathrm{~S}$; the average nitrate concentrations are $257,87 \mathrm{mg} / \mathrm{l}$, and for chlorides the average is $125 \mathrm{mg} / \mathrm{l}$. According to Moroccan groundwater quality standards, these areas are characterized by very poor-quality of water.

On the other hand, for the areas characterized by a very low vulnerability (blue), the average level of electrical conductivity is $847 \mathrm{~S}$; the average nitrate concentrations are in the order of $70.5 \mathrm{mg} / \mathrm{l}$ 
Figure 12. Physico-chemical analysis results according to the DRASTIC index

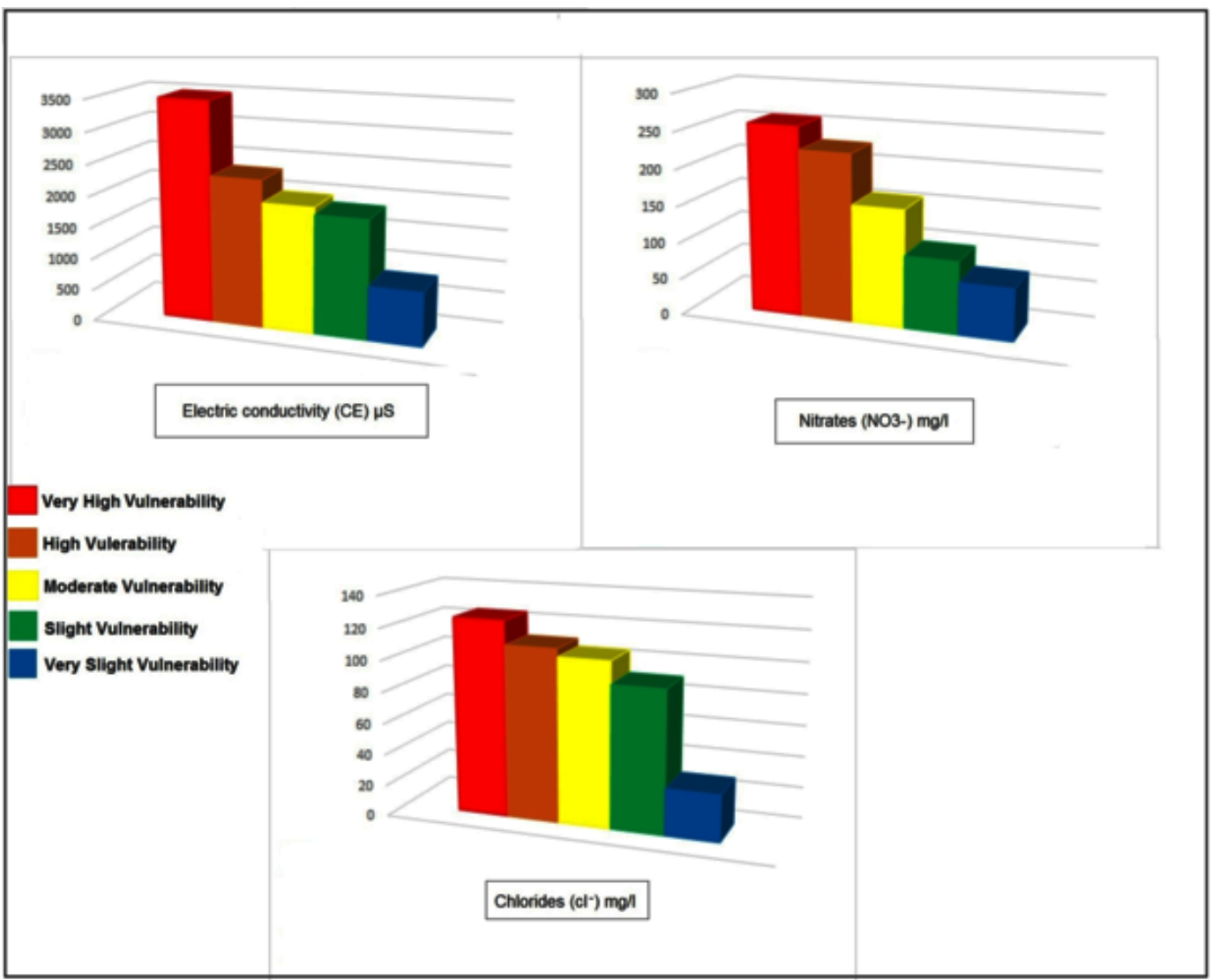

and the average chlorides are $29.82 \mathrm{mg} / \mathrm{l}$. According to Moroccan groundwater quality standards, these areas have a good water quality.

Thus, physic-chemical analyses confirm the results obtained by the DRASTIC method. Therefore, this method remains efficient in assessing the overall intrinsic vulnerability of groundwaters. This claim has been raised also by other authors such as (Arya and al., 2020) in her work, entitled "The study of the vulnerability of groundwater to pollution in the semi-arid basin of the Vattamalaikarai River of southern India in-depth assessment of the DRASTIC index", where the areas of vulnerability of groundwater to pollution of the study area are separated according to three intervals of "high", "moderate" and "low" and illustrated $12 \%$ of the basin area is at high risk, $66 \%$ of the area is in moderate risk and $22 \%$ of the area is safe (low risk). The presence of vulnerable "high" areas is explained by the presence of permeable formations with a shallow water table.

Moreover, (Bera and al., 2021) assess groundwater vulnerability using the GIS-based DRASTIC model in the Nangasai River basin, in India, with a particular focus on agricultural contamination. Bera and his colleagues show that the DRASTIC method presents effective and reliable results, and they validate these results with the results of nitrate analysis in water as well as the TDS (Sulphate and total Dissolved Solids). Therefore, the comparison has revealed a homogeneity of $89 \%$ and $86 \%$ respectively.

In the same vein, another work studies the vulnerability of groundwater to pollution in the SkhiratTémara area using the GOD-Foster method (Taazzouzte and al. 2020). This method, which focuses on the combination of only three criteria, reveals areas of high vulnerability in the Ntord-Ouest near 
the mouth of the Oued Bouregreg where wastewater discharges from the city of Rabat, the salt water treatment plant and drinking water come together (Ain Atiq STEP).

Interestingly, this academic paper has arrived to similar findings. These results are represented by the vulnerability map of groundwater pollution by means of the DRASTIC method. This method which is more precise and detailed since it involves seven parameters that directly influence the vulnerability of water to pollution. Thus, the DRASTIC method remains a primordial tool that helps decision makers and managers of groundwater resources.

\section{CONCLUSION}

The geological and hydrogeological contexts, the depth of the water table and anthropogenic inputs are considered as determining factors in the contamination of groundwater, especially, in the case of the Temara aquifer, since it is an open water table that is recharged only by rainwater.

The vulnerability mapping of the aquifer of Temara has shown the areas of high vulnerability around the city of Rabat, near the mouth of Oued Bouregreg and around the treatment plant of drinking water Ain Atiq. The medium vulnerabilities are located in the southeast (commune of El Menzeh) and south-west of the aquifer (commune of Mers Elkhir), while the low and the very low vulnerabilities are spread in the center of the study area. In order to validate the results of the mapping study, we proceeded to the development of physico-chemical analysis for some elements that have an impact on the quality of water in this aquifer, called the $\mathrm{pH}$ of water, electrical conductivity, nitrates and chlorides.

The comparison of the results obtained by the DRASTIC method have demonstrated a great homogeneity with the results of physico-chemical analyses carried out on samples taken in different classes of vulnerability.

In conclusion, the intervention of new technologies such as geographic information systems (GIS) via modeling in the study of vulnerability to groundwater pollution remains an effective solution that minimizes the costs and time of research. It actually replaces traditional random groundwater sampling methods for monitoring and assessing groundwater quality. In addition, this tool provides decision makers with intrinsic pollution vulnerability maps that allow them to target the most vulnerable areas for further monitoring.

\section{ACKNOWLEDGMENT}

The authors would like to thank the managers of the Bouregreg and Chaouia Hydraulic Basins Agency for their collaboration and support. We also express our sincere gratitude to the anonymous reviews of our work. 


\section{REFERENCES}

ABHBC. (2019). Update study of the Integrated Water Resources Development Master Plan for the Bouregreg and Chaouia hydraulic basins. Bouregreg and Chaouia Hydraulic Basin Agency.

Abiy Anteneh, Z., Melesse Assefa, M., \& Behabtu Yewendwesen, M. (2016). Groundwater Vulnerability Analysis of the Tana Sub-Basin: An Application of DRASTIC Index Method. Academic Press.

Agossou, A., \& Yang, J-S S. (2021). Comparative Study of Groundwater Vulnerability to Contamination Assessment Methods Applied to the Southern Coastal Sedimentary Basin of Benin. Journal of Hydrology: Regional Studies, 35(July), 100803. .10.1016/j.ejrh.2021.100803

Akil, M. (1980). Contribution to the sedimentological study of Quaternary coastal formations in the region of Rabat (Morocco). D. E. S. Mohmed V University.

Aller, L., Bennet, T., Lehr, J. H., \& Petty, R. J. (1987). DRASTIC: A Standardized System for Evaluating Groundwater Pollution Potential Using Hydro Geologic Settings. National Water Well Association.

Amraoui, F. (2000). Hydrochemical study of the Temara and coastal Chaouia aquifers (Moroccan Meseta). Bulletin of the Scientific Institute, 22, 71-80.

Aravinthasamy, P., Karunanidhi, D., Subramani, T., Anand, B., Roy, P. D., \& Srinivasamoorthy, K. Fluoride contamination in groundwater of the Shanmuganadhi River basin (south India) and its association with other chemical constituents using geographical information system and multivariate statistics, Geochemistry, Volume 80, Issue 4, Supplement, 2020,125555, ISSN 0009-2819, doi:10.1016/j.chemer.2019.125555

Arya, S., Subramani, T., Vennila, G., \& Roy, P. D. Groundwater vulnerability to pollution in the semi-arid Vattamalaikarai River Basin of south India thorough DRASTIC index evaluation, Geochemistry, Volume 80, Issue 4, Supplement, 2020,125635, ISSN 0009-2819, doi:10.1016/j.chemer.2020.125635

Ball, D., Macdonald, A., \& Dochartaigh, B. (2004). Development of a Groundwater Vulnerability Screening Methodology for the Water Framework Directive. Final report. Project WFD28. SNIFFER. https://www.sniffer. org.uk/wfd28-pdf

Beaudet, G. (1969). The central Moroccan plateau and its borders: geomorphological study (Doctoral thesis). Mohammed V University, Rabat.

Beaudet, G., Maurer, G., \& Ruellan, A. (1967). The Moroccan Quaternary. New observations and hypotheses. Journal of Physical Geography and Dynamic Geology, 9(4), 269-310.

Bera, A., Bhabani, P. M., Puja, C., Argha, G., \& Swagata, B. (2021). Groundwater Vulnerability Assessment Using GIS-Based DRASTIC Model in Nangasai River Basin, India with Special Emphasis on Agricultural Contamination. Ecotoxicology and Environmental Safety, 214, 112085. doi:10.1016/j.ecoenv.2021.112085 PMID:33690007

Bhuvaneswaran, C., \& Ganesh, A. (2019). Spatial Assessment of Groundwater Vulnerability Using DRASTIC Model with GIS in Uppar Odai Sub-Watershed, Nandiyar, Cauvery Basin, Tamil Nadu. Groundwater for Sustainable Development, 9(December), 100270. .10.1016/j.gsd.2019.100270

Boulabeiz, M., Klebingat, S., Agaguenia, S. (2019). A GIS-based GOD model and hazard index analysis: The quaternary coastal collo aquifer (NE-Algeria). Groundwater, 57(1).

Civita, M. (1994). Le Carte Della Vulnerability adegli Acquiferi All'inquinamento: Teoriaepractica (Aquifer Vulnerability Maps to Pollution). Pitagora.

Combe, M. (1963). Hydrogeological study of the Lalla Mimouna region. Kenitra: National Office for Irrigation.

Doerfliger, N., \& Zwahlen, F. (1997). EPIK: A New Method for Outlining of Protection Areas in Karstic Environment. Proceedings of the International symposium and field seminar on karst waters and environmental impacts, 117-123.

Duarte, L., Teodoro Ana, C., Gonçalves José, A., Dias António, J.G., \& Marques Jorge, E. (2020). Assessing Groundwater Vulnerability to Pollution through the DRASTIC Method A GIS Open Source Application. Academic Press. 
Foster, S. S. D. (1987). Fundamental concepts in aquifer vulnerability, pollution risk and protection strategy. In W. van Duijvenbooden \& H. G. van Waegeningh (Eds.), Vulnerability of Soil and Groundwater to Pollutants (pp. 69-86). Proceedings and Information.

Gad, M., \& El-Hattab, M. (2019). Integration of Water Pollution Indices and DRASTIC Model for Assessment of Groundwater Quality in El Fayoum Depression, Western Desert, Egypt. Journal of African Earth Sciences, 158(July), 103554. doi:10.1016/j.jafrearsci.2019.103554

GCPH. (2014). General Census of Population and Habitat. high commission for the plan of Morocco. Note on the first results of the General Population and Habitat Census. GCPH.

Guilcher, A., \& Joly, F. (1954). Research on the morphology of the Atlantic coast of Morocco. Trav. Inst. Sc., Ser. Geol. Géo. Phy., 2, 140.

Javadi, S., Hashemy Shahdany, S. M., Neshat, A., \& Chambel, A. (2020). Multi-parameter risk mapping of qazvin aquifer by classic and fuzzy clustering techniques. Geocarto International, 1-20. doi:10.1080/101060 49.2020 .1778099

Khosravi, K., Sartaj, M., Tsai, F. T. C., Singh, V. P., Kazakis, N., Melesse, A. M., Prakash, I., Tien Bui, D., \& Pham, B. T. (2018). A Comparison Study of DRASTIC Methods with Various Objective Methods for Groundwater Vulnerability Assessment. The Science of the Total Environment, 642, 1032-1049. doi:10.1016/j. scitotenv.2018.06.130 PMID:30045486

Knouz, N., Boudhar, A., \& Bachaoui, E. et al.. (2018). Comparative approach of three popular intrinsic vulnerability methods: Case of the Beni Amir groundwater (Morocco). Arabian Journal of Geosciences, 11, 281. https://doi.org/10.1007/s12517-018-3596-1

Lefèvre, D., \& Raynal, J.-P. (2002). The plio-pleistocene formations of Casablanca and the chronostratigraphy of the Marine Quaternary of Morocco revisited. Quaternary, 13(1), 9-21. doi:10.3406/quate.2002.1700

Li, P., He, S., Yang, N., \& Xiang, G. (2018). Groundwater quality assessment for domestic and agricultural purposes in Yan' an City, northwest China: Implications to sustainable groundwater quality management on the Loess Plateau. Environmental Earth Sciences, 77(23), 775. doi:10.1007/s12665-018-7968-3

Mahmudul, H., \& Ashraful, Md. I., Aziz H. M., Md. Jahangir, A., Mehedi Hasan, P. (2019) Groundwater vulnerability assessment in Savar upazila of Dhaka district, Bangladesh - A GIS-based DRASTIC modeling, Groundwater for Sustainable Development, Volume 9, 2019, 100220, ISSN 2352-801X, doi:10.1016/j. gsd.2019.100220

Margat, J. (1968). Groundwater vulnerability to contamination. Basics of Cartography, 68.

Nekkoub, A., Baali, F., Hadji, R., \& Hamed, Y. (2020). The EPIK multi-attribute method for intrinsic vulnerability assessment of karstic aquifer under semi-arid climatic conditions, case of Cheria Plateau, NE Algeria. Arabian Journal of Geosciences, 13(15), 1-15. doi:10.1007/s12517-020-05704-0

Noori, R., Ghahremanzadeh, H., Kløve, B., Adamowski, J. F., \& Baghvand, A. (2019). Modified-DRASTIC, modified-SINTACS and SI methods for groundwater vulnerability assessment in the southern Tehran aquifer. Journal of Environmental Science and Health. Part A, Environmental Science and Engineering \& Toxic and Hazardous Substance Control, 54(1), 89-100. doi:10.1080/10934529.2018.1537728 PMID:30596317

Pathak, D. R., \& Bhandary, N. P. (2020). Evaluation of groundwater vulnerability to nitrate in shallow aquifer using multi-layer fuzzy inference system within GIS environment. Groundwater for Sustainable Development, 11, 100470. doi:10.1016/j.gsd.2020.100470

Rahmani, B., Javadi, S., \& Shahdany, S. M. H. (2019). Evaluation of aquifer vulnerability using PCA technique and various clustering methods. Geocarto International, 1-24. doi:10.1080/10106049.2019.1690057

SEEE. (2007). Water Quality Standard for Irrigation Rabat. Secretary of State to the Ministry of Energy, Mines, Water.

Stearns, C. E. (1978). Pliocene-Pleistocene emergence of the Moroccan Meseta. Geological Society of America Bulletin, 89(11), 1630-1644. doi:10.1130/0016-7606(1978)89<1630:PEOTMM>2.0.CO;2 
Taazzouzte, M., Ghafiri, A., Lemacha, H., \& El Moutaki, S. (2020). Study of intrinsic vulnerability to pollution by the GOD-Foster method: Application to temara groundwater (Morocco). GEP, 08(08), 129-142. doi:10.4236/ gep. 2020.88010

Taazzouzte, M. (2002). Diagnosis of the state of the environment in the region of Missour (Dissertation). Fac. Sci. Kénitra, Morocco.

Tomer, T., Deeksha, K., \& Varun, J. (2019). Sensitivity Analysis of Groundwater Vulnerability Using DRASTIC Method: A Case Study of National Capital Territory, Delhi, India. Groundwater for Sustainable Development, 9(July), 100271. doi:10.1016/j.gsd.2019.100271

Van Stempvoort, D., Evert, L., \& Wassenaar, L. (1993). Aquifer vulnerability index: A GIS compatible method for groundwater vulnerability mapping. Canadian Water Resources Journal, 18(1), 25-37. doi:10.4296/cwrj1801025

Voudouris, K., Kazakis, N., Polemio, M., \& Kareklas, K. (2010). Assessment of intrinsic vul- nerability usin the DRASTIC model and GIS in the Kiti Aquifer. Cyprus. European Water, 3, 13-24.

Voutchkova, Schullehner, Rasmussen, \& Hansen. (2021). A High-Resolution Nitrate Vulnerability Assessment of Sandy Aquifers (DRASTIC-N). Journal of Environmental Management, 277.

Wang, D., Wu, J., Wang, Y., \& Ji, Y. (2019). Finding high-quality groundwater resources to Reduce the Hydatidosis incidence in the Shiqu County of Sichuan Province, China: Analysis, assessment, and management. Exposure and Health. Advance online publication. doi:10.1007/s12403-019-00314-y

Weisrock, A. (1980). Geomorphology and Paleoenvironments of the Atlantic Atlas, Morocco, Thesis, Paris 1. Notes and Memoirs of the Geological Service of Morocco, 332, 487.

Weisrock, A., \& Fontugne, M. (1991). Coastal Aeolian Morphogenesis in the Upper Pleistocene and the Holocene in the Moroccan Atlantic Ooulja. Quaternary, 2(3-4), 164-175. doi:10.3406/quate.1991.1965 